\title{
Assessment of the acid phosphatase CP01850 from Corynebacterium pseudotuberculosis in DNA and subunit vaccine formulations \\ against caseous lymphadenitis
}
[Avaliação da fosfatase ácida recombinante CP01850 de Corynebacterium pseudotuberculosis em formulações vacinais de subunidade e de DNA contra a linfadenite caseosa]




\section{INTRODUCTION}

Caseous lymphadenitis (CLA) is a chronic, infectious disease caused by Corynebacterium pseudotuberculosis mainly affecting small ruminants. CLA has a worldwide distribution and a high prevalence is described especially in countries where sheep and goat farming is an important economic activity, resulting in major economic losses (Seyffert et al., 2010). Antibiotic therapy becomes difficult because the drugs cannot reach $C$. pseudotuberculosis in encapsulated lesions (Pépin and Paton, 2011). This bacterium is sensitive to some antimicrobial agents such as planktonic form but is highly resistant when it forms biofilms (Olson et al., 2002). In addition, some commercial vaccines induce side effects such as cutaneous granuloma formation, edema, fever and drop in milk production and provide just partial protection (Williamson, 2001).

As an attempt to solve those problems, experimental DNA and recombinant subunit vaccines have been developed. The DNA vaccine pTARGET/cp09720 induced a significant increase in IFN- $\gamma$ levels, indicating a Th1 response, the phenotype related to CLA protection (Brum et al., 2017). Also, recombinant subunit vaccines have been tested for CLA immune prophylaxis, since they are considered safe for inducing lower levels of side effects, resulting in variable protection rates depending on the $C$. pseudotuberculosis antigen selected (Hodgson et al., 1999; Pinho et al., 2009; Silva et al., 2014; Droppa-Almeida et al. 2016; Brum et al. 2017; Silva et al., 2018).

Bioinformatic approaches have made a more efficient selection of antigens to be used in recombinant vaccines for CLA possible. The pan-secretome of $C$. pseudotuberculosis was submitted to Mature Epitope Density (MED) Analysis (Santos et al., 2013). As a result, the acid phophatase encoded by the cp1002_RS01850 gene (former cp1002_0369), the target focused here, was ranked as the third most immunogenic target for use in CLA vaccines (Rezende et al., 2016).

Our group has recently demonstrated that rCP01850 protein associated with rPLD in a saponin-adjuvanted vaccine significantly increases the protection rate and IFN- $\gamma$ mRNA levels against CLA (Silva et al., 2018). However, the use of the recombinant acid phosphatase CP01850 alone in CLA vaccines was not demonstrated yet. In this study, we explored the potential of DNA and subunit recombinant vaccines for CLA constructed with the target cp1002_RS01850 from C. pseudotuberculosis. The formulations were tested in mice and the protective potential and elicited immune response were described.

\section{MATERIALS AND METHODS}

In this study, $C$. pseudotuberculosis strains Mic6 and Cp1002 and Escherichia coli strains TOP10 and BL21(DE3) Star were used. $C$. pseudotuberculois was cultured in Brain Heart Infusion (BHI) media supplemented with $0.5 \%$ Tween 80 at $37^{\circ} \mathrm{C}$ for $72 \mathrm{~h}$ under stirring. For cultures on solid media, $1.5 \%$ bacteriological agar was added to the culture medium. E. coli was grown in Luria Bertani medium (LB), or LB supplemented with $1.5 \%$ bacteriological agar for $16 \mathrm{~h}$ at $37^{\circ} \mathrm{C}$. Ampicillin $(100 \mu \mathrm{g} / \mathrm{mL})$ was added to the LB medium when necessary.

Cloning of cp1002_RS01850 gene was performed in $E$. coli TOP 10 cells using pAE vector. Protein expression was performed in $E$. coli BL21 (DE3) through the recombinant plasmid pAE/cp01850 according to described by Rezende et al. (2016). To determine antigenicity of rCP01850 recombinant protein, a Western blot analysis was performed using positive $(n=10)$ and negative $(n=1)$ sheep serum samples for CLA. Samples containing $5 \mu \mathrm{g}$ of $\mathrm{rCP} 01850$ were mixed with SDS sample buffer (100-mM Tris$\mathrm{HCl}$ pH 6.8 buffer, 100-mM 2-mercaptoethanol, $4 \%$ SDS, and $0.2 \%$ bromophenol blue, $20 \%$ glycerol) under reducing conditions, heated to $100^{\circ} \mathrm{C}$ for $10 \mathrm{~min}$, and then submitted to electrophoresis in a $12 \%$ SDS-PAGE. Afterwards, the proteins were electrically transferred to a nitrocellulose membrane (GE Healthcare). The membrane was blocked with $5 \%$ skim milk PBS for $1 \mathrm{~h}$ at $37^{\circ} \mathrm{C}$. Sheep serum was added to the membrane at a dilution of 1:100 (each serum) at $37^{\circ} \mathrm{C}$ for $1 \mathrm{~h}$. The membranes were washed with PBS $0.05 \%$ tween (PBS-T) and incubated with sheep anti-IgG conjugated with peroxidase (Sigma), diluted to $1: 6,000$ in PBS-T at $37^{\circ} \mathrm{C}$ for $1 \mathrm{~h}$. Reactive bands were exposed using 3,3'-diaminobenzidine (DAB) and $\mathrm{H}_{2} \mathrm{O}_{2}$. 
For DNA vaccine construction, cp1002_RSO1850 gene was amplified by PCR, as described by Rezende et al. (2016), and cloned into pTARGET vector using pTARGET TM Mammalian Expression Vector System (Promega), according to the manufacturer's instructions. The ligation product was used to transform $E$. coli TOP10 by electroporation. The transformation product was cultured in LB medium containing $100 \mu \mathrm{g} / \mathrm{mL}$ ampicillin, and 20mg/mL X-Gal (5-bromo-4-chloro-3-indoxyl- $\beta$ D-galactopyranoside) (Invitrogen). The recombinant colony containing pTARGET/cp01850 was selected and the clone was grown in $200 \mathrm{~mL}$ of liquid LB with $100 \mu \mathrm{g} / \mathrm{mL}$ ampicillin. DNA was extracted on a large scale using the Perfectprep Plasmid Maxi kit (Eppendorf).

In vitro protein expression was assessed in Chinese Hamster Ovary (CHO) cells cultured in 96-well micro-titer plates containing DMEM (Dulbecco's Modified Eagle's Medium). After achieving $80 \%$ confluence, the cells were transfected with $1 \mu \mathrm{g}$ DNA of pTARGET/cp01850 or pTARGET plasmids using Lipofectamine TM 2000 (Invitrogen). After $48 \mathrm{~h}$ of incubation, in vitro expression of CP01850 protein was assessed by indirect immunofluorescence assay (IFA) using antirCP01850 polyclonal antibodies (1:100) produced in mice, and polyclonal mouse antiIgG antibodies conjugated with FITC (fluorescein isothiocyanate) (1:80) (Millipore).

For the immunization assay, five groups containing eight $\mathrm{BALB} / \mathrm{c}$ mice of six to eight weeks age each were inoculated on days 0,21 , and 42. The animals were divided into the following groups: G1 inoculated with DNA vaccine $(100 \mu \mathrm{L}) \quad$ containing $50 \mu \mathrm{g}$ pTARGET/cp01850 in each dose; G2, inoculated with $100 \mu \mathrm{L}$ rCP01850 recombinant vaccine $(50 \mu \mathrm{g})$ associated with aluminum hydroxide adjuvant $\mathrm{Al}(\mathrm{OH})_{3}(15 \%$, v/v) in each dose; G3, inoculated on day 0 and day 21 with the DNA vaccine (pTARGET/cp01850), and on day 42 with a boost of recombinant subunit vaccine $\mathrm{rCP} 01850 / \mathrm{Al}(\mathrm{OH})_{3}$ as described before; G4, negative control, inoculated with $100 \mu \mathrm{L}$ of the DNA vaccine containing 50 $\mathrm{\mu g}$ pTARGET; and G5, negative control, inoculated with $100 \mu \mathrm{L}$ solution aluminum hydroxide $(15 \%)$. All groups were administered intramuscularly (i.m). Blood samples from the retro-orbital plexus were taken on days 0,21 , and 42 and the serum were stored at $-20^{\circ} \mathrm{C}$ until $\mathrm{IgG}$ level determination by ELISA.

In each group, five animals were challenged while the other three were used in cellular immune response experiment. The challenge was performed 21 days after the last inoculation with $10^{4} \mathrm{CFU} / \mathrm{mL}$ of $C$. pseudotuberculosis Mic-6 strain administered intraperitoneally (Silva et al., 2014). The animals were monitored for 30 days after the challenge. Experiments involving animals were conducted in accordance with the recommendations of the Brazilian College of Animal Experimentation (COBEA). The procedures were in accordance with the National Council for Animal Experiments Control (CONCEA, $\mathrm{n}^{\circ}$ 11794), and approved by the Ethics Committee in Animal Experimentation from the Federal University of Pelotas (No. 2442).

Immunoglobulin detection was performed through indirect ELISA. Polystyrene 96-well plates (Nunc-Maxisorp) were coated with $100 \mu \mathrm{L}$ of the solution containing carbonate bicarbonate buffer $\mathrm{pH}$ 9.6, and 100ng/well of rCP01850. Plates were then incubated at $4^{\circ} \mathrm{C}$ for $18 \mathrm{~h}$. Plates were then washed with PBS-T (1X PBS pH 7.4, $0.05 \%$ Tween 20), and were blocked with $200 \mu \mathrm{L} /$ well of $5 \%$ skim milk diluted in PBS-T for $2 \mathrm{~h}$ at $37^{\circ} \mathrm{C}$. After blocking, the plates were washed three times with PBS-T. Serum samples $(100 \mu \mathrm{L} /$ well $)$ at 1:50 dilution in PBS-T were added in duplicate. After one hour of incubation at $37^{\circ} \mathrm{C}$, and three washes with PBS-T, $100 \mu \mathrm{L} /$ well of anti-IgG whole mouse antibody (Sigma-Aldrich) diluted 1:5,000 in PBS-T was added. For detection of IgG1 and IgG2a isotypes, anti-IgG1 and anti-IgG2a produced in goat (Sigma-Aldrich) at a dilution of 1:5,000 and 1:2,000 in PBS-T, respectively, were added. The plates were incubated for $1 \mathrm{~h}$ at $37^{\circ} \mathrm{C}$ and then five washes with PBS-T were performed. In plates used for isotype detection, an additional step of adding anti-goat antibody conjugated to peroxidase (Sigma-Aldrich) diluted to 1:5000 in PBS-T was performed. After $1 \mathrm{~h}$ of incubation at $37^{\circ} \mathrm{C}$ and five washes with PBS-T, $100 \mu \mathrm{L} /$ well of the substrate-chromogen solution $[o-$ phenylenediamine dihydrochloride; OPD tablets (Sigma-Aldrich) in $0.4 \mathrm{mg} / \mathrm{mL}$ phosphate-citrate buffer containing $0.04 \%$ of $30 \%$ hydrogen 
peroxide $\mathrm{pH}=5.0]$ was added. The plates were incubated at room temperature in the dark for $15 \mathrm{~min}$ and the reaction was stopped by adding $50 \mu \mathrm{L} /$ well of stop solution containing $4 \mathrm{~N}$ sulfuric acid. The optical density (OD) at $450 \mathrm{~nm}$ was determined using a microtiter plate reader (Microplate Reader, Mindray).

Twenty-one days after the last immunization, three mice from each experimental group were sacrificed, the spleens were removed and homogenized for splenocyte isolation. Spleen cell suspensions obtained from each animal were placed in complete RPMI medium (RPMI 1640 medium - Gibco BRL supplemented with $10 \%$ fetal bovine serum, $100 \mathrm{IU} / \mathrm{mL}$ penicillin, and $100 \mu \mathrm{g} / \mathrm{mL}$ of streptomycin - LGC Bio), and counted in a Neubauer chamber. Cell concentration was adjusted to $2 \times 10^{6}$ cells $/ \mathrm{mL}$. Viability was tested with Trypan Blue dye (Vetec). A total of $2 \times 10^{5}$ cells $(100 \mu \mathrm{L})$ were distributed in triplicate, into 24 -well plates
(Maxisorp, Nunc). For each group, cells were stimulated with sterile PBS (negative control), $15 \mu \mathrm{g}$ rCP01850, or $8 \mu \mathrm{g} / \mathrm{ml}$ concanavalin A (ConA) (positive control) and incubated at $5 \%$ $\mathrm{CO}_{2}$ and $37^{\circ} \mathrm{C}$ for $72 \mathrm{~h}$ (maximum). Splenocytes were used for total RNA extraction using Trizol (Invitrogen), following the manufacturer's recommendations. The cDNA synthesis was performed starting from $1 \mu \mathrm{g}$ total RNA using the High Capacity cDNA Reverse Transcription Kit ${ }^{\circledR}$ according to the manufacturer's recommended protocol (Applied Biosystems). The cDNA was used to quantify the expression of the cytokines IL-4, IL-10, IL-12, and IFN- $\gamma$ by real time PCR using a Stratagene Mx3005P Real Time PCR System (Agilent Technologies), and Syber Green reagent (Applied Biosystems). The rate of gene expression was calculated relative to the expression of the GAPDH gene, based on the method described by Pfaffl et al. (2001). The primers used here are described in Table 1.

Table 1. Features of the primers used in qRT-PCR to determine cytokine relative expression in mice immunized with DNA or recombinant subunit vaccines engineered with the target cp1002_RSO1850 from C. pseudotuberculosis

\begin{tabular}{|c|c|c|c|}
\hline Gene & Primer Sequences & $\mathrm{TM}^{*}$ & Reference \\
\hline IL-4 & $\begin{array}{l}\text { F 5' CCAAGGTGCTTCGCATATTT 3' } \\
\text { R 5' ATCGAAAAGCCCGAAAGAGT 3' }\end{array}$ & $60^{\circ} \mathrm{C}$ & Jacob et al. (2011) \\
\hline IL-10 & $\begin{array}{l}\text { F 5', TTTGAATTCCCTGGGTGAGAA 3', } \\
\text { R 5'ACAGGGGAGAAATCGATGACA 3, }\end{array}$ & $60^{\circ} \mathrm{C}$ & Cardona et al. (2003) \\
\hline IL-12 & $\begin{array}{l}\text { F 5' AGCACCAGCTTCTTCATCAGG 3' } \\
\text { R 5' CCTTTCTGGTTACACCCCTCC 3' }\end{array}$ & $60^{\circ} \mathrm{C}$ & Cardona et al. (2003) \\
\hline IFN- $\gamma$ & $\begin{array}{l}\text { F 5' GCGTCATTGAATCACACCTG 3', } \\
\text { R 5', TGAGCTCATTGAATGCTTGG 3', }\end{array}$ & $60^{\circ} \mathrm{C}$ & Jacob et al. (2011) \\
\hline GAPDH & $\begin{array}{l}\mathrm{F} \text { '5' AACGCCCTTCATTGAC 3' } \\
\text { R 5' TCCACGACATACTCAGCAC 3' }\end{array}$ & $60^{\circ} \mathrm{C}$ & Matsui et al. (2012) \\
\hline
\end{tabular}

$* \mathrm{TM}=$ Melting temperature

Results were expressed as mean \pm standard deviation. Differences between the experimental groups were calculated using one-way ANOVA followed by Tukey's test (post-test levels of protection, immunoglobulin and cytokine production). The Fisher's test and the Wilcoxon $\log$ rank test were used to determine significant differences in mortality and survival rates. Data were considered significantly different when $\mathrm{P}<$ 0.05. Both tests were performed using GraphPad Prism software (GraphPad Software, San Diego California, USA), version 5.0.

\section{RESULTS}

The protein $\mathrm{rCP} 01850$ was recognized by sera from sheep with CLA, confirming its antigenicity (Figure 1). Moreover, an intense fluorescence was observed in $\mathrm{CHO}$ cells transfected with pTARGET/cp01850, demonstrating the in vitro expression of rCP01850. In contrast, cells transfected with pTARGET vector (negative control) showed no fluorescence (Figure 2).

ELISA results showed a significant production by G2 of IgG total, IgG1 and IgG2a on day 21 post-immunization (Figure 3). G3 and G1 also 
demonstrated significantly higher levels of IgG1 on day 21 post-immunization. However, on day 42 post-immunization, there was a significant increase in total IgG levels for G1 animals. Still on day 42 post-immunization, G2 and G3 showed higher IgG total, IgG1, and IgG2a levels $(\mathrm{P}<0.05)$, in comparison to other groups (Figure $3 \mathrm{~A}, 3 \mathrm{~B}$ and $3 \mathrm{C}$ ).

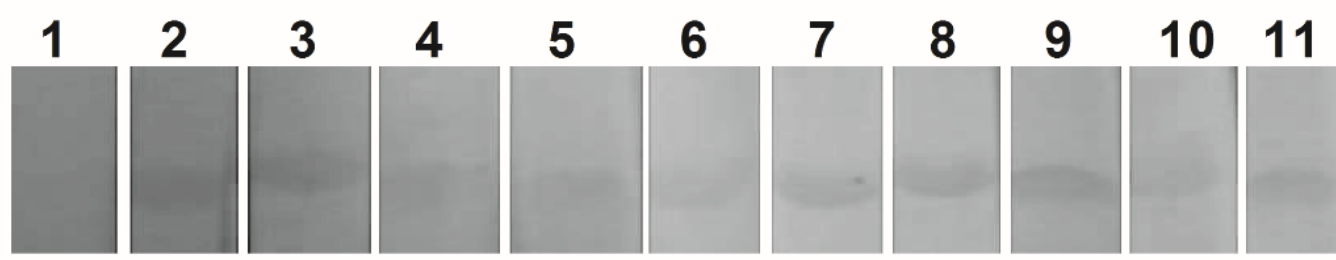

Figure 1. Western blot of rCP01850 expressed in Escherichia coli. Antigenicity was determined using protein using positive and negative sheep sera for CLA. (1) Negative sheep serum. (2 to 11) Positive sheep sera from 10 animals with clinical CLA.

\section{(A)}

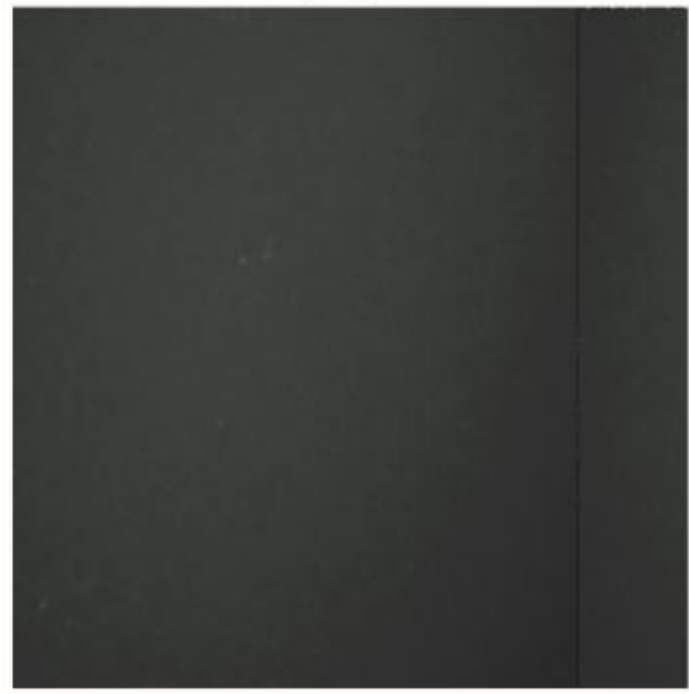

(B)

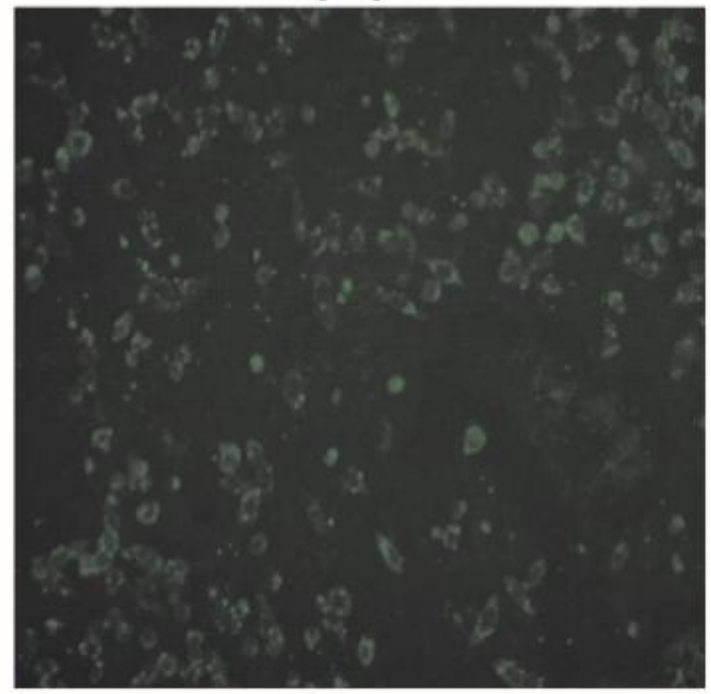

Figure 2. Indirect immunofluorescence showing in vitro expression of CP01850 protein in Chinese Hamster Ovary (CHO) cells transfected with DNA vector pTARGET (A) or recombinant pTARGET/cp01850 (B). Cells were transfected with $1 \mu \mathrm{g}$ plasmid DNA, and after 48h, incubated with anti-rCP01850 polyclonal antibodies produced in mice, followed by incubation with fluorescein (FITC)conjugated anti-mouse IgG.

Using real-time PCR, we estimated the transcription levels of the cytokines IL-4, IL-10, IL-12, and IFN- $\gamma$ (Figure 4). The results showed that $\mathrm{G} 2$, inoculated with $\mathrm{rCP} 01850 / \mathrm{Al}\left(\mathrm{OH}_{3}\right)$, induced higher levels of IL-4, IL-12 and IFN- $\gamma$ in comparison to the other groups $(\mathrm{P}<0.05)$, while G3, the group where the prime-boost strategy was used, showed significant levels of IL-10 (P< 0.05). 

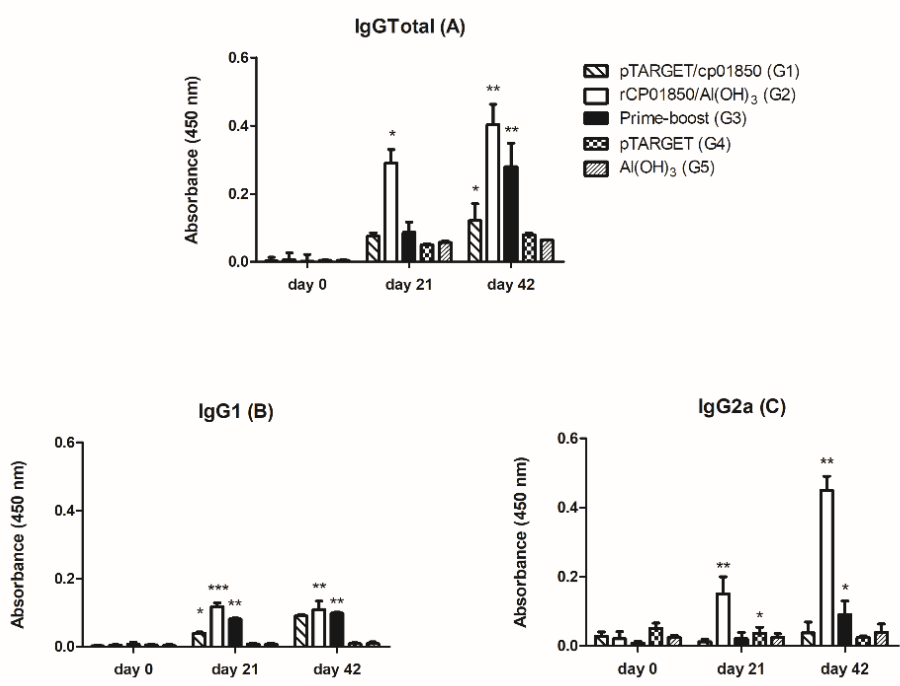

Figure 3. Mean (columns) and standard deviation (bars) of absorbances (nm) for IgG total (A), IgG1 (B) and IgG2a (C) levels in BALB/c mice immunized with DNA and/or recombinant subunit vaccines engineered with target cp1002_RS01850 from C. pseudotuberculosis. Eight animals per group were inoculated with: pTARGET/cp01850 (G1); rCP01850 plus aluminum hydroxide adjuvant $\mathrm{Al}(\mathrm{OH})_{3}(\mathrm{G} 2)$; prime-boost strategy inoculated with two doses of pTARGET/cp01850, and a final boost rCP01850/Al $(\mathrm{OH})_{3}(\mathrm{G} 3)$; pTARGET $(\mathrm{G} 4)$; or $\mathrm{Al}(\mathrm{OH})_{3}(\mathrm{G} 5)$. Each animal was inoculated with three doses on days 0,21 , and 42 of the experiment, and blood samples were individually taken on the same days. Indirect ELISA with rCP01850 was used to determine IgG total, IgG1 and IgG2a levels. * Significantly higher results $(\mathrm{P}<0.05)$ compared to controls. ** Significantly higher results $(\mathrm{P}<0.05)$ compared to the other experimental groups. $* * *$ Significantly higher results $(\mathrm{P}<0.05)$ compared to the controls and to the other experimental groups.
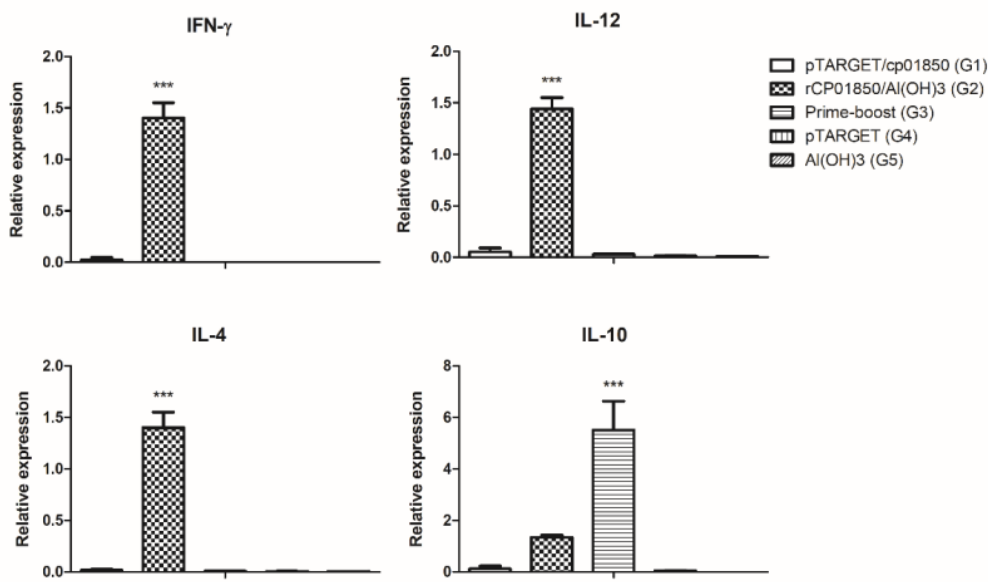

Figure 4. Mean (columns) and standard deviation (bars) of IL-4, IL-10, IL-12, and IFN- $\gamma$ mRNA relative expression by qRT-PCR induced in splenocyte cell culture samples from mice immunized with DNA and/or recombinant subunit vaccines engineered with target cp1002_RS01850 from C. pseudotuberculosis. Each mouse was inoculated with three doses on days 0, 21, and 42 of the experiment using: pTARGET/cp01850 (G1); rCP01850 plus aluminum hydroxide adjuvant $\mathrm{Al}(\mathrm{OH})_{3}(\mathrm{G} 2)$; prime-boost strategy inoculated with two doses of pTARGET/cp01850, and a final boost $\mathrm{rCP} 01850 / \mathrm{Al}(\mathrm{OH})_{3}(\mathrm{G} 3)$; pTARGET $(\mathrm{G} 4)$; or $\mathrm{Al}(\mathrm{OH})_{3}(\mathrm{G} 5)$. Twenty-one days after the last immunization, three mice in each group were sacrificed and the splenocytes isolated. After $72 \mathrm{~h}$ of stimuli with $15 \mu \mathrm{g}$ rCP01850, sterile PBS (negative control) or concanavalin A (positive control), total RNA was extracted, converted to cDNA and used in qRT-PCR to quantify the expression of the cytokines IL-4, IL-10, IL-12, and IFN- $\gamma$. The rate of gene expression was calculated relatively to the expression of the GAPDH gene. Results are the mean from two independent experiments. $* * *$ Significantly higher results $(\mathrm{P}<0.05)$ compared to controls and other experimental groups. 
After the challenge, all animals in G1, G3, G4 and $\mathrm{G} 5$ died between the 12 th and 17 th postchallenge day (Figure 5). However, it is important to highlight that G2 showed an increase in the survival rate $(\mathrm{P}<0.05)$ and the last death was observed late, on day 24 postchallenge.

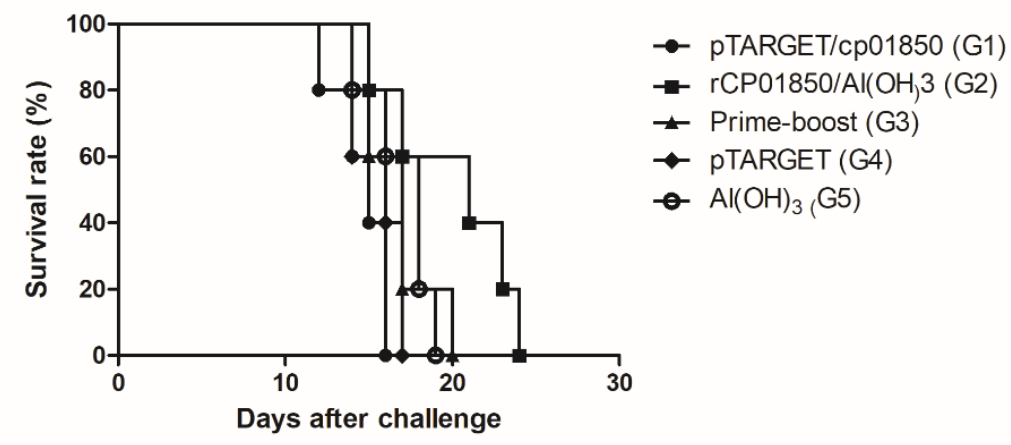

Figure 5. Survival curve of the mice immunized with DNA and/or recombinant subunit vaccines engineered with target cp1002_RS01850 from C. pseudotuberculosis. Twenty-one days after the last immunization, five mice in each experimental group were challenged with $10^{4} \mathrm{CFU} / \mathrm{mL}$ of $C$. pseudotuberculosis Mic-6 strain. The animals were monitored for death until the $24^{\text {th }}$ day after challenge.

\section{DISCUSSION}

Many studies have been conducted searching for new targets to be used in CLA vaccine formulations, especially through bioinformatic approaches (Santos et al., 2012; Silva et al., 2013; Rezende et al., 2016). However, few studies effectively showed the production and evaluation of recombinant vaccines against CLA. In the present work the target cp1002_RSO1850 from $C$. pseudotuberculosis was evaluated in a recombinant subunit vaccine using aluminum hydroxide as adjuvant, and in a DNA vaccine. None of the vaccine strategies used here were effective in conferring protection against a challenge with the $C$. pseudotuberculosis Mic-6 strain. However, it is important to highlight that G2 showed an increase in the survival rate, which may be associated with higher levels of IgG1 and IgG2a observed on 21- and 42-days postimmunization. Mice from $\mathrm{G} 2$ produced a more accentuated level of $\operatorname{IgG} 2 \mathrm{a}$ in comparison to $\operatorname{IgG} 1$, and this fact may be associated with a Th1 response since in mice, production of the $\operatorname{IgG} 2 \mathrm{a}$ isotype is a marker for a Th1 type response and is directly related to immunity against intracellular pathogens (Mountford et al., 1994).

Similar results were reported when rPLD and rHsp60 proteins were used in recombinant subunit vaccines against CLA, wherein the survival rate increased, although formulations failed in conferring protection in $C$. pseudotuberculosis challenge (Fontaine et al., 2006; Pinho et al., 2009). We hypothesized that the use of only rCP01850 is possibly insufficient to provide adequate levels of protection, requiring an evaluation of which important recombinant proteins related to $C$. pseudotuberculosis pathogenesis should be associated to improve protection. In fact, in recent publication, our group has demonstrated that when $\mathrm{rCP} 01850$ protein was associated to rPLD in a saponin-adjuvanted vaccine, protection rate was improved by $20 \%$ in comparison to the use of rPLD alone, and a significant $(\mathrm{P}<0.05)$ production of IFN- $\gamma$ in mice was obtained, demonstrating the benefit of including rCP01850 in CLA vaccine formulations (Silva et al., 2018). So, rCP01850 had an additive effect in formulations containing more than one protein, but here, the same protein was insufficient for conferring protection when used alone adjuvanted with aluminum hydroxide.

Mice immunized with $\mathrm{rCP} 01850 / \mathrm{Al}(\mathrm{OH})_{3}$ had increased levels of IL-4, IL-12 and IFN- $\gamma$. Former studies have shown that the development of a Th1 (cellular), or a Th2 (humoral) response profile is mainly dependent on the balance between IFN- $\gamma$ and IL-12 (which favors the Th1 response), and IL-4 (which promotes response Th2) (Gherardi et al., 2000). Thus, it is suggested that the animals immunized with $\mathrm{rCP} 01850 / \mathrm{Al}$ 
$(\mathrm{OH})_{3}$ developed a mixed Th1/Th2 profile, which would be most appropriate for combating C. pseudotuberculosis, at once characterized as a facultative intracellular pathogen possibly requiring both immune responses to be eliminated. However, no protection was observed in any of the tested groups. We hypothesized that higher levels of these cytokines are needed for protection against CLA, which may be achieved through the combination with more potent adjuvants.

In this work we used aluminum hydroxide as adjuvant associated to $\mathrm{rCP} 01850$ protein. It is known that adjuvants are particularly important for both recombinant subunit and DNA vaccines, which tend to be poorly immunogenic, not eliciting a protective response when used alone. It is necessary to find the best combination of antigen and adjuvant in the ideal vaccine formulation (Guy, 2007). Further studies are already being carried out to evaluate the effectiveness of other adjuvants in association with rCP01850. Saponin seems to be a promising adjuvant for recombinant CLA vaccines for its ability to stimulate Th1 and cytotoxic T lymphocytes responses (Bastos et al., 2013). Silva et al. (2014) obtained protection levels of up to $90 \%$ with a formulation containing $\mathrm{rCP} 40$ antigen from $C$. pseudotuberculosis associated to saponin.

Another promising vaccinal strategy is the heterologous prime-boost done with different types of vaccines containing the same antigens. In some cases, this strategy is more efficient inducing higher levels of protection (Lu, 2009). However, mice immunized with heterologous prime-boost strategy (G3) here showed higher IL-10 levels. This cytokine is responsible for inhibiting macrophage migration during inflammatory reactions (Kaplan et al., 2003), which is possibly the cause for the low cellular immune response levels in this group, and consequently the protective failure.

\section{CONCLUSIONS}

All the approaches to immunize with subunit recombinant and DNA vaccines formulations using the acid phosphatase CP01850 assessed in this study did not confer protection against virulent $C$. pseudotuberculosis challenge in mice. On the other hand, the association of $\mathrm{rCP} 01850$ with aluminum hydroxide increased the postchallenge survival rate, through a mixed Th1/Th2 immune response type induction. Further studies employing the target cp1002_RSO1850 from C. pseudotuberculosis in other vaccine approaches will be performed to improve its efficacy.

\section{ACKNOWLEDGMENTS}

The authors gratefully acknowledge the financial support provided by the Foundation for Rio Grande do Sul State Research (FAPERGS) [grant number 11/1894-0].

\section{REFERENCES}

BASTOS, B.L.; LOUREIRO, D.; RAYNAL, J.T. et al. Association between haptoglobin and IgM levels and the clinical progression of caseous lymphadenitis in sheep. BMC Vet. Res., v.13, p.254, 2013.

BRUM, A.A.; REZENDE, A.F.S.; BRILHANTE, F.S. et al. Recombinant esterase from Corynebacterium pseudotuberculosis in DNA and subunit recombinant vaccines partially protect mice against challenge. $J$. Med. Microbiol., v.66, p.635-642, 2017.

CARDONA, P.J.; GORDILLO, S.; DÍAZ, J. et al. Widespread bronchogenic dissemination makes DBA/2 mice more susceptible than C57BL/6 mice to experimental aerosol infection with Mycobacterium tuberculosis. Infect. Immun., v.71, p.5845-5854, 2003.

DROPPA-ALMEIDA, D.; VIVAS, W.L.; SILVA, K.K. et al. Recombinant CP40 from Corynebacterium pseudotuberculosis confers protection in mice after challenge with a virulent strain. Vaccine, v.34, p.10911096, 2016.

FONTAINE, M.C.; BAIRD, G.; CONNOR, K.M. et $a l$. Vaccination confers significant protection of sheep against infection with a virulent United Kingdom strain of Corynebacterium pseudotuberculosis. Vaccine, v.24, p.5986-5996, 2006.

GHERARDI, M.M.; RAMÍREZ, J.C.; ESTEBAN, M. Interleukin-12 (IL-12) enhancement of the cellular immune response against human immunodeficiency virus type 1 env antigen in a DNA prime/vaccinia virus boost vaccine regimen is time and dose dependent: suppressive effects of IL-12 boost are mediated by nitric oxide. J. Virol., v.74, p.6278-6286, 2000.

GUY, B. The perfect mix: recent progress in adjuvant research. Nat. Rev. Microbiol., v.5, p.505-517, 2007. 
HODGSON, A.L.M.; CARTERB, K.; TACHEDJIANA, M. et al. Efficacy of an ovine caseous lymphadenitis vaccine formulated using a genetically inactive form of the Corynebacterium pseudotuberculosis phospholipase D. Vaccine, v.17, p.802-808, 1999.

JACOB, E.; HOD-DVORAI, R.; BEN-MORDECHAI, L. et al. Dual function of polycomb group proteins in differentiated murine T helper (CD4+) cells. J. Mol. Signal., v.6, p.5, 2011.

KAPLAN, E.H.; CRAFT, D.L.; WEIN, L.M. Analyzing bioterror response logistics: The case of smallpox. Math. Biosci., v.185, p.33-72, 2003.

LU, S. Heterologous prime-boost vaccination. Curr. Opin. Immunol., v.2, p.346-351, 2009.

MATSUI, H.; YOKOYAMA, T.; TANAKA, C. et al. Pressure mediated hypertrophy and mechanical stretch up-regulate expression of the long form of leptin receptor $(\mathrm{ob}-\mathrm{Rb})$ in rat cardiac myocytes. BMC Cell Biol., v.13, p.37, 2012.

MOUNTFORD, A.P.; FISHER, A.; WILSON, R.A. The profile of IgG1 and IgG2a antibody responses in mice exposed to Schistosoma mansoni. Parasite Immunol., v.16, p.521-527, 1994.

OLSON, M.E.; CERI, H.; MORCK, D.W. et al. Biofilm bacteria: formation and comparative susceptibility to antibiotics. Can. J. Vet. Res., v.66, p.86-92, 2002.

PÉPIN, M.; PATON, M.W. Caseous lymphadenitis in sheep and goats. In: LEFEVRE, P.C.; BLANCOU, J.; CHERMETTE, R. et al. (Eds.). Infectious and parasitic diseases of livestock. Paris: Lavoisier, 2011. p.1153-1165.

PFAFFL, M.W. A new mathematical model for relative quantification in real-time RT-PCR. Nucl. Acids Res., v.29, p.e45, 2001.

PINHO, J.M.R.; DORELLA, F.A.; COELHO, K.S. et al. Immunization with recombinant Corynebacterium pseudotuberculosis heat-shock protein (Hsp)-60 is able to induce an immune response in mice, but fails to confer protection against infection. Open Vet. Sci. J., v.3, p.22-27, 2009.
REZENDE, AF.; BRUM, A.A.; REIS, C.G. et al. In silico identification of Corynebacterium pseudotuberculosis antigenic targets and application in immunodiagnosis. J. Med. Microbiol., v.65, p.521529, 2016.

SANTOS, A.R.; CARNEIRO, A.; GALA-GARCÍA, A. et al. The Corynebacterium pseudotuberculosis in silico predicted pan-exoproteome. BMC Genomics, v.13, Suppl.5, p.S6, 2012.

SANTOS, A.R.; PEREIRA, V.B.; BARBOSA, E. et al. Mature epitope density - a strategy for target selection based on immunoinformatics and exported prokaryotic proteins. BMC Genomics, v.14, Suppl.6, p.S4, 2013.

SEYFFERT, N.; GUIMARÃES, A.S.; PACHECO, L.G. et al. High seroprevalence of caseous lymphadenitis in Brazilian goat herds revealed by Corynebacterium pseudotuberculosis secreted proteins-based ELISA. Res. Vet. Sci., v.88, p.50-55, 2010.

SILVA, J.W.; DROPPA-ALMEIDA, D.; BORSUK, S. et al. Corynebacterium pseudotuberculosis cp09 mutant and cp40 recombinant protein partially protect mice against caseous lymphadenitis. BMC Vet. Res., v.10, p.965, 2014.

SILVA, M.T.O.; BEZERRA, F.S.B.; PINHO, R.B. et al. Association of Corynebacterium pseudotuberculosis recombinant proteins $\mathrm{rCP} 09720$ or rCP01850 with rPLD as immunogens in caseous lymphadenitis immunoprophylaxis. Vaccine, v.36, p.74-83, 2018.

SILVA, W.M.; SEYFFERT, N.; SANTOS, A.V. et al. Identification of 11 new exoproteins in Corynebacterium pseudotuberculosis by comparative analysis of the exoproteome. Microb. Pathog., v.6162, p.37-42, 2013.

WILLIAMSON, L.H. Caseous lymphadenitis in small ruminants. Vet. Clin. N. Am. Food Anim. Pract., v.17, p.359-371, 2001. 